\title{
How glucagon-like is glucagon-like peptide-1?
}

\author{
M. Ghiglione, L. O. Uttenthal, S. K. George and S. R. Bloom \\ Department of Medicine, Royal Postgraduate Medical School, Hammersmith Hospital, London, UK
}

\begin{abstract}
Summary. Although glucagon-like peptide- 1 has the appearance of a glucagon-homologue that may be co-secreted with glucagon, synthetic glucagon-like peptide-1-(1-37) does not significantly affect plasma glucose and insulin concentrations when administered at high doses (100 and $400 \mu \mathrm{g}$ ) to cortisone-pretreated rabbits. This synthetic preparation thus lacks
\end{abstract}

the primary metabolic effect of glucagon at the doses tested. An intra- or extra-pancreatic role of glucagon-like peptide-1 has yet to be discovered.

Key words: Glucagon-like peptide-1, glucose, insulin, glucagon, bioassay.
The nucleotide sequences of cDNA derived from hamster [1] and ox [2] glucagon mRNA and the human preproglucagon gene [3] show that pre-proglucagon contains two further glucagon-like peptides (GLP-1 and -2) $\mathrm{C}$-terminal to the glucagon sequence. The amino-acid sequence of GLP-1 is completely conserved between the three mammalian species studied and shows a high degree of homology with similar deduced amino-acid sequences in angler-fish pre-proglucagons [4]. It is defined by delimiting pairs of basic amino-acid residues, that form potential cleavage points. GLP-1 thus has the appearance of a highly conserved biologically active peptide that may be co-secreted with glucagon, and it is possible that it has a modulating role in carbohydrate metabolism. In the first instance we have tested synthetic GLP-1 for its effect on plasma glucose and insulin concentrations in rabbits.

\section{Material and methods}

Synthetic GLP-1-(1-37) was synthesized by a solid phase method [5] (Bachem, Torrance, CA, USA). It was tested for its effect on plasma glucose and insulin by a modification of the twin cross-over bioassay for glucagon [6], using crystalline glucagon (Novo Industri, Copenhagen, Denmark) as a standard. Twelve rabbits were injected $(25 \mathrm{mg}$ subcutaneously) on day 0 with cortisone acetate injection (British Pharmacopoeia; Cortistab, The Boots Company, Nottingham, UK). The assay was performed on days 2 and 3 , the rabbits being deprived of food for $18 \mathrm{~h}$ before each part of the assay, but with free access to water. The peptides were dissolved immediately before each experiment in $1.6 \%(\mathrm{vol} / \mathrm{vol})$ aqueous glycerine containing $0.2 \%(\mathrm{wt} / \mathrm{vol})$ phenol, adjusted to $\mathrm{pH} 3$ with $\mathrm{HCl}$.
The rabbits were randomized into four groups of three each, and they received a subcutaneous injection of $1 \mathrm{ml}$ of diluent, as a control, followed after $60 \mathrm{~min}$ by either GLP-1 ( $400 \mu \mathrm{g}$ or $100 \mu \mathrm{g}$ ) or glucagon $(24 \mu \mathrm{g}$ or $6 \mu \mathrm{g})$ in the same volume. Blood samples $(0.3 \mathrm{ml})$ were taken from a marginal ear vein at times $-40,0,20$ and $60 \mathrm{~min}$ in relation to both the diluent and peptide injections. The next day, the experiment was repeated with a twin cross-over, so that rabbits that had received the higher dose of glucagon now received the lower dose of GLP-1. The blood samples were collected into fluoride-oxalate centrifuge tubes, containing dried aprotinin (200 Kallikrein Inhibitor Units; Trasylol, Bayer, Wuppertal, FRG), and centrifuged immediately at $1600 \mathrm{~g}$ for $10 \mathrm{~min}$. The plasma was frozen on solid $\mathrm{CO}_{2}$ and stored at $-20^{\circ} \mathrm{C}$. Plasma glucose concentrations were determined with a glucose analyzer (No.2, Beckman Instruments, Fullerton, California, USA), and immunoreactive insulin was determined by radioimmunoassay [7]. Results were analysed by Student's paired t-test on $\log$ transformed data.

\section{Results}

Plasma glucose and immunoreactive insulin concentrations obtained at $20 \mathrm{~min}$ after the injection of diluent controls, GLP-1 at doses of $400 \mu \mathrm{g}$ and $100 \mu \mathrm{g}$ and glucagon at doses of $24 \mu \mathrm{g}$ and $6 \mu \mathrm{g}$ are shown in Figure 1. Glucagon produced the expected significant increases in plasma glucose and insulin concentrations, whereas GLP-1 had no effect on plasma glucose at either dose. This was also the case at $60 \mathrm{~min}$ after injection. The slight increases in the mean plasma insulin concentration seen $20 \mathrm{~min}$ after GLP-1 injections persisted at $60 \mathrm{~min}$ with the $400 \mu \mathrm{g}$ dose, but not with the $100 \mu \mathrm{g}$ dose, and were not statistically significant on a paired basis. 

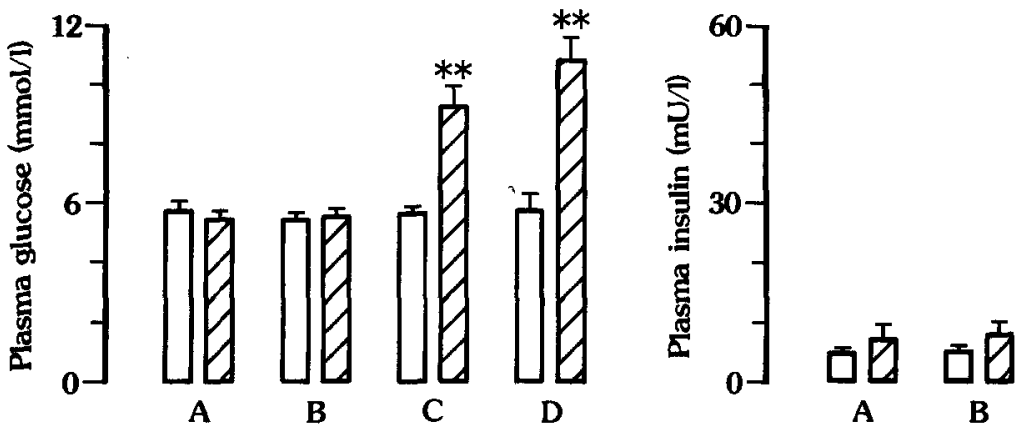

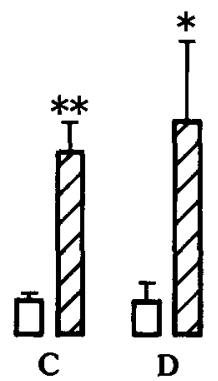

Fig. 1. Plasma glucose and insulin concentrations in rabbits $20 \mathrm{~min}$ after injection of $\square(n=6)(\mathrm{A})$ GLP-1 $100 \mu \mathrm{g}$, (B) GLP-1 $400 \mu \mathrm{g}$, (C) glucagon $6 \mu \mathrm{g}$, (D) glucagon $24 \mu \mathrm{g}$, compared with their respective control values $20 \mathrm{~min}$ after diluent injections $\square$. Bars represent mean and SEM; ${ }^{* *} p<0.001,{ }^{*} p<0.05$

Table 1. Amino-acid sequences of GLP-1 and pancreatic glucagon [1]

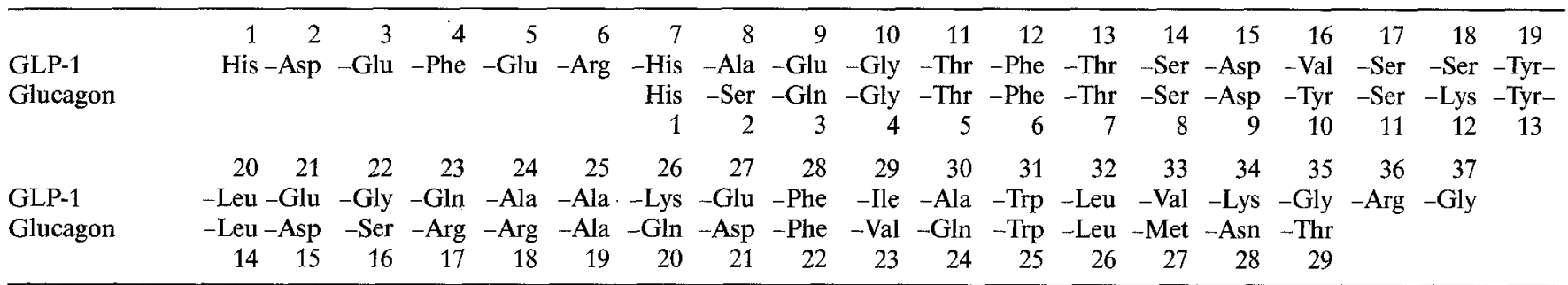

\section{Discussion}

Despite the sequence homology between GLP-1 and glucagon (14 out of 29 comparable residues), GLP-1 does not affect plasma glucose concentrations, even at the high doses used in this study. It must therefore possess considerably less than $1 \%$ of the hyperglycaemic activity of glucagon, $2 \mu \mathrm{g}$ doses of which produce detectable responses in the assay used [6]. The full aminoacid sequences of GLP-1 and glucagon are shown in Table 1 . The similarity between glucagon and GLP-1 is greatest in the first nine residues of glucagon, where there are seven amino-acid identities; but GLP-1 has a further six amino-acid residues extending its $\mathrm{N}$-terminal region beyond that of glucagon. As $\mathrm{N}$-terminally extended forms of glucagon do not interact with hepatic glucagon receptors [8], the $\mathrm{N}$-terminal extension of GLP-1, is only one of several structural features that may prevent binding to glucagon receptors. However, this study shows that GLP-1 does not produce a hyperglycaemic effect by an alternative mechanism. There remains the possibility that GLP-1 has a weak effect on insulin release, requiring higher doses or a larger number of animals than were available in this study for a significant release to be demonstrated. While this points to a possible role for GLP-1 within the islet, GLP-1 receptors have yet to be identified in any tissue, and any definite intra- or extra-pancreatic role remains to be discovered.

Acknowledgements. This work was supported by the Spanish Ministry of Education and Science (MG) and the Medical Research Council of Great Britain (LOU and SKG).

\section{References}

1. Bell GI, Santerre RF, Mullenbach GT (1983) Hamster preproglucagon contains the sequence of glucagon and two related peptides. Nature 302: 716-718

2. Lopez LC, Frazier ML, Su C-J, Kumar A, Saunders GF (1983) Mammalian pancreatic preproglucagon contains three glucagonrelated peptides. Proc Natl Acad Sci USA 80: 5485-5489

3. Bell GI, Sanchez-Pescador R, Laybourn PJ, Najarian RC (1983) Exon duplication and divergence in the human preproglucagon gene. Nature 304: 368-371

4. Lund PK, Goodman RH, Montminy MR, Dee PC, Habener JF (1983) Angler-fish islet pre-proglucagon. II. Nucleotide and corresponding amino acid sequence of the cDNA. J Biol Chem 258: 3280-3284

5. Merrifield RB (1963) Solid phase synthesis. J Am Chem Soc 85: 2149-2156

6. Tarding F, Nielsen P, Keiser-Nielsen B, Nielsen AV (1969) Biological assay of glucagon in rabbits. Diabetologia $5: 146-154$

7. Albano JDM, Ekins RP, Maritz G, Turner RC (1972) A sensitive, precise radioimmunoassay of serum insulin relying on charcoal separation of bound and free hormone moieties. Acta Endocrinol 70: 487-509

8. Holst JJ (1983) Gut glucagon, enteroglucagon, gut glucagon-like immunoreactivity, glicentin - current status. Gastroenterology 84 : $1602-1613$

Received: 8 May 1984

and in revised form: 16 August 1984

Dr. M. Ghiglione

Department of Medicine

Royal Postgraduate Medical School

Hammersmith Hospital

Du Cane Road

London W12 OHS, UK 